\title{
Sharia Philosophy Correlation and the Islamic Economic Philosophy
}

\author{
Hendrianto $^{1}$, Juhaya S. Praja ${ }^{2}$, Nurrahman $^{3}$ \\ ${ }^{1}$ Institut Agama Syariah Negeri Curup, Indonesia \\ 2,3UIN Sunan Gunung Djati Bandung, Indonesia \\ Email: hendrianto9909@gmail.com
}

\section{Abstract:}

This study aims to reveal the relationship between Islamic philosophy and Islamic economic philosophy, both in terms of foundation, operation, and objectives. This library research (Library Research) uses documentation data collection techniques with data analysis, namely content analysis. The results showed that the relationship between sharia philosophy and sharia economic philosophy is that there is a philosophical foundation based on al-qur'am, hadith, ijma 'and qiyas, as well as operational principles, observations are made, take generalization conclusions and serve as theory, while the goal is both want to get happiness in the world and the hereafter, but what distinguishes the two lies in the broader study of sharia philosophy and complexity, while Islamic economic philosophy specializes in sharia economic studies. But for sharia economic philosophy discusses tauhid, caliphate, tazkiyah, and masuliyya. Operational principles, observing, drawing conclusions and making theory. The goal of obtaining falah, namely survival, freedom of desire, and strength and honor.

Keywords:

linkage; philosophy; economics; sharia

\section{Introduction}

Sharia philosophy is always thinking freely which is still in the corridor of Islamic law in order to get peace of mind, it is neutral, does not take sides with the interests of a group of people but always upholds the safety and peace of all people. Sharia philosophy is the result of philosophical thinking about divinity, prophethood, humanity and nature which is illuminated by Islamic teachings in a broad logical and systematic rule of thought about existing theory (ontology), showing his views on space, time, matter and life (Sulaiman. A, 2016).

Sharia philosophy combines thought with revelation, this shows that revelation does not contradict reason and vice versa, likewise revelation regulates humans and nature. In the sense that revelation always guides the study of humans and nature, so that revelation cannot be abandoned or set aside. The revelation in question is the kalamullah (the words of Allah), namely the al-qur'an.

Al-Quran which is the main source of Islamic teachings has stipulated various rules as guidance for mankind (both Islam and other religions) in carrying out activities in every aspect of their life including in the economic field.

The development of the sharia economic philosophy comes from the Muslims themselves, because their understanding does not contradict revelation. However, currently Muslims are relatively ignorant of sharia economic philosophy, in the end some people think that sharia economics is the same as conventional. 
Economit Journal: Scientific Journal of Accountancy, Management and Finance ISSN: 2775-5827 (Online), 2775-5819 (Print)

Vol. 1, No. 1, February 2021, Page: 12-20

Email: economitjournal@gmail.com

Regions that already have the authority to implement Islamic law in Aceh and run the wheels of the sharia economy use Islamic financial institutions, M. Shabri said that there are still many financial, banking and non-banking institutions that operate ribawi in Aceh. Bank Aceh, which is owned by the Acehnese, is still reluctant to be transformed into a fully Islamic bank. In fact, the ulama, the Islamic Sharia Service, media activists, the DPRA, elements of community organizations and the Acehnese people are very supportive of making Bank Aceh a truly Islamic bank (Ade Fadillah Fw Pospos, 2015).

Many do not know that the Prophet Muhammad was a businessman since childhood. He herd livestock to train little Muhammad to have good leadership and management skills. Herding goats can foster an attitude of tenderness, patience and humility. Shepherding is also an educational suggestion for managing humans and organizing life and is also a good form of business/business (Novi Indriyani Sitepu, 2016).

Inner satisfaction or what is called success is found in those who actually run the sharia economy. Because the economy is a basic necessity in fulfilling human welfare. In conventional economics, welfare is defined as self-satisfaction as much as great, whereas in Islamic economics welfare is defined as the success of life in the world in carrying out its duties as a Caliph to worship Allah (Agus Arwani, 2012).

Many Islamic countries are involved in international trade. This is because no country is able to isolate itself in the realm of the global economy. The world community in an economic perspective is a society integrated by one world system to seek a new form of economic order that is more just. In this conceptualization, each business actor is free to choose a profitable transaction system and maintain the stability of the profits (Bambang Wahyu, 2011).

The explanation above shows that it is necessary to review the studies of sharia philosophy and sharia economic philosophy. So that the understanding of the appropriateness of the Islamic economic philosophy in society can be obtained properly, so that it can be implemented in Islamic economic practice. This article attempts to examine the relationship between Islamic philosophy and Islamic economic philosophy.

\section{Review of Literatures}

\subsection{Characteristics of Islamic Philosophy}

To make it easier to understand the characteristics of Islamic philosophy, it is detailed in the following explanation (Achmad Gholib, 2009)

\section{a. The Foundation of 'Thinking}

Islamic philosophy is based on Islamic religious principles, namely the Qur'an and hadith. So the source of knowledge in Islamic philosophy is the arguments of revelation and rational arguments ('aqli). In general, all scholars, both eastern and western, believe that the Qur'an and hadith play an important role in the development of philosophical thought in Islam, this can be seen from some of the ideas conveyed by Muslim philosophers such as alKindi who divided the field of Islamic philosophy into three. parts namely physics, mathematics and divinity. 
So the main and foremost source of thinking to understand Islamic philosophy is the Al-Quran and Hadith, these two sources are the primary sources that must be used as a reference for philosophers, especially Islamic philosophers. Muslims, without exception, if they want to be separated from their heretical patterns of thought, they must use the principles and sources of the Qur'an and Hadith.

\section{b. Analysis System}

The analysis system is to promote the unification of the rational and spiritual system. A rational system that is applied normatively by giving birth to beliefs and beliefs that always prioritizes their relationship with God. Al-Farabi felt disappointed with Aristotle's book entitled metaphysics which did not mention much about God, while in Islam this is the main theme for discussing the Oneness of God. Aristotle only touched on God a little deeplythe book of Lambda even then there is no satisfactory description of how God created nature.

\section{c. The Subject of the Reviewer}

Islam must give birth to Muslim philosophers, meaning that this philosophical study was carried out by Muslims. Besides mastering God's language, he also knows what God expects. It is possible that Islamic philosophers could be born from non-Arab people, like Ibn Sina who was born from Persia, Al-Farabi was born from Turkey.

\section{d. Object Under Study}

Material and formal objects, namely god, man and nature. In order to specialize in the field of study because the discussion of these three objects also gave birth to other sciences, several themes were determined which only Muslim philosophers discussed and did not become discussions in other scientific fields.

\section{e. Field of Study}

Ontology is studying the nature of existing existence, only based on logic alone, not up to the research stage. Epistemology is to discuss the source of human knowledge through the verses of the Al-Quran and hadith using methodology, to find the result, namely axiology. Axiology discusses whether the results of this epistemology are valuable or neutral (value free).

\subsection{Characteristics of Sharia Economics}

The characteristics of the Islamic economy are as follows (IY Fauzia, 2014) :

a. Rabbaniyah Mashdar (sourced from God). Islamic economics (Al-Iqtishad Al-Islami) is a teaching that comes from Allah. This statement can be scrambled in several texts of the Qur'an and Hadith that appeared in the 6th century AD.

b. Rabbaniyah Al-Hadf (aim for God). Apart from coming from God, Sharia economics aims at Allah, meaning that all sharia economic activities are a form of worship which is manifested in human relationships to build a relationship with Allah.

c. Al-Raqabah Al-Mazdujah (mixin control / control inside and outside). Islamic economy includes inherent supervision for all humans involved in it. Because humans are leaders (khalifah for themselves).

d. Al-Jam'u Baina Al-Tsabat wa Al-Murunah (a combination of fixed and soft). This is related to law in sharia economics. Islam allows its followers to have economic activities freely, as long as it does not contradict the prohibitions which mostly result in losses to others. 
e. Al-Tawazun Bayna Al-Maslahah Al-Fard wa Al-Jama'ah (balance between the benefit of individuals and society). Islamic economy is an economy that leads to a high balance between the benefit of individuals and society.

f. Al-Tawazun Bayna Al-Madiyah wa Al-Rukhiyah (balance between material and spiritual). Islam motivates people to work and seek existing sustenance and Islam does not prohibit its people from utilizing existing sustenance.

g. Al-Waqiyah (realistic). Islamic economy is realistic, because the existing system is in accordance with the real conditions of society.

h. Al-Alamiyyah (universal). Islam has a very universal system. Therefore, its teachings can be practiced by anyone and wherever they are.

\section{Research Methods}

This paper is a literature review (Library Research), with the source of data coming from secondary data, namely dokuumentation in the form of writings related to sharia philosophy and sharia economic philosophy. The data sources are in the form of scientific articles and books. To analyze the data, the researcher used content analysis, namely analyzing all related written data sources, then finding the relationship between Islamic philosophy and Islamic economic philosophy. The results of the study were expressed in a descriptive qualitative manner.

\section{Results and Discussion}

Sharia philosophy is related to Islamic economic philosophy in this case seen from the philosophical foundation, operational principles, and objectives to be achieved. So in this case the two studies cannot be separated because sharia economic philosophy is part of the study of sharia philosophy. The relationship between Islamic philosophy and Islamic economic philosophy is as follows:

\subsection{Correlation of the Foundation of Sharia Philosophy and Sharia Economic Philosophy}

A foundation is a starting point or a foothold carried out by a person as a controller in carrying out activities in order to achieve the desired goals. If this foundation is not clear, the goal will be difficult to achieve, on the other hand, if this foundation is clear and directed, the goal will be easily achieved.

In general, the runway is divided into two, namely, First, material runways, among others, are in the form of aircraft runways and building foundations. And second, conceptual foundations include the foundation of the Indonesian State, namely Pancasila and the 1945 Indonesian Constitution; educational foundation, and so on (Muhammad Arif, 2018).

Likewise in Islam, it has a conceptual basis that becomes the guidelines for Muslims in their actions, namely the Al-Quran, Hadith, Ijma ', Qiyas and so on. Al-Qur'an as a foundation as well as a guide for human life. All matters relating to human life are regulated in the AlQuran. From waking up to going back to sleep, everything is regulated in Islam. Al-Quran, Hadith, Ijma ', and Qiyas are called the foundation of Islamic sharia.

The conceptual foundation of sharia philosophy above has a direct relationship with the Islamic economic philosophy, but formally the Islamic economic philosophy limits it only to concepts related to Islamic economics, as an effort to find and develop economic concepts 
based on Sharia values and teachings (Arif, 2018). The philosophical foundation of Sharia economics includes:

\section{a. Tawheed}

The general foundation of sharia economics is tauhid which states the oneness of Allah SWT, everything on this earth is His creation and He is also the one who has the power to save everything both in heaven and on earth. This shows that Allah is all-powerful, all-wise. Tawhid is divided into two rububiyah and uluhiyah, namely:

1. Rububiyah

Rububiyah monotheism is the monotheism of Allah in events that can only be done by Allah SWT, and states firmly that Allah is Rabb, the king and creator of all creatures and Allah is the one who governs and changes their situation (Syakh Muhammad Bin Abdul Wahab).

So the meaning of tauhid rububiyah is to affirm Allah in terms of His power over the omnipresence of creation, ownership, and maintenance in the heavens and on earth.

2. Uluhiyah

Tauhid Uluhiyah is obeying Allah in all forms of worship, both zohir and inner (Syakh Muhammad Bin Abdul Wahab). So uluhiyah are all actions that are done only to get closer to Allah, Zohir for example providing for the family for the head of the family, a teacher to teach, and so on, as well as inwardly the intention and goal is only to get pleasure.

Allah has the power to create nature and choose all of its contents. For this reason, all activities carried out by humans should have the value of worship with Allah SWT. Humans, as the most glorious creatures on the surface of this earth, must always show their devotion by not causing harm to themselves or the universe, as well as in bermuamalah according to the principles of sharia economics.

\section{b. Khilafah}

The Khilafah in question is government, which plays a full role in upholding the economy and includes the sharia economy, it can be assumed that if the government's attention is more towards sharia economic growth, then the development of the sharia economy will be better too. This can be seen to what extent the government's role is in improving or developing the Islamic economy.

\section{c. Tazkiyah}

A Muslim must realize that humans are never free from mistakes, both our mistakes towards Him and the mistakes of other human beings. In an economy that is very vulnerable to fraud that occurs, the solution is tazkiyah or self-purification, so that we return to nature.

\section{d. Mas'uliyah}

Humans are leaders and will be held accountable, in this case whatever their daily actions will be held accountable. A farmer is held accountable, a trader is held accountable, and a businessman is held accountable. Responsibility is considered good if all activities are intended to only hope for the pleasure of Allah SWT, save oneself, make the best use of nature and provide benefits to fellow humans.

All the philosophical foundations of sharia economics above provide guidelines for sharia-based economic activities, both in terms of production, distribution and consumption. The foundation of the sharia economic philosophy above controls humans so that they are able to control themselves not to make mistakes in economic activities. 
The foundation of the Islamic economic philosophy is based on the concept of a triangle, namely the philosophy of God, man and nature. The key to sharia economic philosophy lies in the relationship between humans and God, the universe with other God's creatures (A Harisah, 2018).

The explanation above explains the concept of man with God and man with nature. In order for economic activity to be of worship value with Allah SWT, vertical relations must be good and horizontal relationships are also good. For this reason, Islamic economic philosophy must be able to synergize with conventional, making Islamic economics popular with many groups, both sharia and non-sharia circles, this shows that sharia economics is rahmatan lil 'alamin.

\subsection{Operational Correlation of Sharia Philosophy and Sharia Economic Philosophy}

The operational principle is a pattern for a person or group to make choices in order to get inner satisfaction from the results that have become decisions. The operational principle in sharia philosophy is referred to as a commitment to implementing sharia in a kaffah manner, trying not to make sharia a symbol or recognition. Philosophy is needed by humans in an effort to answer questions that arise in various fields of human life. The answer is the result of systematic, integral, comprehensive and basic thinking (Harisah, 2018).

It is the same with the operational principles of sharia economic philosophy which states that the principle is the choice to carry out the commitment of sharia economic activities. However, sharia philosophy is broader while sharia economic philosophy is only related to the production, distribution and consumption period, in this case also explained by Maulana Malik Kandhalwi, he divides 12 themes of Islamic economic studies as follows (Ridha, muhammad Rasid) :

1. Ownership

2. Wealth

3. Looking for fortune

4. Soil

5. Labor

6. Capital

7. Consumer attitude

8. Market mechanism

9. Money and credit

10.State finances

11.Economic development

12.Economic values

From the aforementioned study themes, it gives birth to the limitations of sharia economics as a sharia economic philosophy agreement. To carry out the operational principles of sharia economics:

\section{a. Observation (empirical) Social Symptoms of Society}

Carrying out economic activities at the present time it is very necessary to make observations by collecting concrete data to be adjusted to the philosophical basis, so that errors do not occur.

Given the importance of empirical observations, it was initially pioneered by Aristotle and finally received a great reception in the classical era of sharia by Muslim philosophers, such as Ibn Sina, Al-Faraby, Al-Kindy, Ibn Rusydi, Ibn Maskawaih and others, even Ibn 
Taimiyyah. In fact, he developed many empirical methods even though he was not influenced by Greek philosophy. Subsequently developed by Farncis Bocan which has an important role in the induction method and systematic scientific procedures. It is practical, that is, to give humans power over nature through scientific investigation (Arwani, 2012).

The explanation above explains that observations are made practically and systematically can be used as an understanding that will produce conclusions, to produce conclusions, empirical observations are made. For example, in economics we see business ethics, of course, must be based on Islamic law and then done critically and practically so as to produce temporary conclusions.

\section{b. Take Generalized Conclusions}

Drawing conclusions from observational activities is of course a serious and good effort, by researching economic studies to draw conclusions from the results of studies that have been carried out.

Conclusions are the result of the observations made, as explained generalization is a statement about the relationship between concepts and serves to assist and facilitate understanding of the intent of the statement, serves to identify causes and effects, and can even be used to predict an event related to existing statements. in the generaliusation in a sense, a generalization is also a simple statement to a more complex one (Banks J.A, 1990).

From the above explanation, the conclusions of the results from the observation are similar to that in Islamic economics when observing related to economic studies will produce conclusions.

\section{c. Making Theory}

Basically, the theory has been proven correct, so that it can be used as a science. For Islam and sharia economics, the most authoritative sources of knowledge are the Al-Quran and Hadith, but the existence of sharia economics is more limited than conventional, even though if it is seen from history that the western economy is partly sourced from sharia philosophy, in this case the sharia theory needs to be maintained and developed again.

As a basis for developing the theory of sharia philosophy, of course it is not limited to rationalism and experience because there are still other ways, namely intuition or revelation. Intuition is knowledge that is obtained without going through a process of reasoning, is personal and unpredictable. Meanwhile, revelation is knowledge conveyed by God to humans (Mohammadadib, 2011).

From the above explanation, it has been illustrated that proving the truth of Islamic economic philosophy must be on a rational mind not against reason, empirical (experience) and al-qur'an and hadith

\subsection{Correlation of Sharia Philosophy Objectives and Sharia Economic Philosophy}

Life has goals to be achieved, namely planning, both short-term, mid-term, and longterm, the planned goals vary from one another.

The objective of sharia philosophy is to get closer to the creator in order to carry out sharia properly and properly. The uses of philosophy can be divided into two, namely general and specific uses. First, general utility means the benefits that can be taken by those who study philosophy deeply so that they are able to critically solve problems about everything. Second, 
the use is specifically intended to solve an object in Indonesia. So, specifically means bound by time and space, general means that it is not bound by space and time (Mohammadadib, 2011).

The more development of science makes the field of study of sharia philosophy increase, so philosophy must be able to solve problems critically and perfectly both at an unlimited level and at a limited level, in order to give birth to rational and positivistic sharia sciences. Likewise with the sharia economic philosophy which aims to solve problems in a critical way, but the Islamic economic philosophy always provides a simple but clear and firm aim motto, namely falah, which means obtaining happiness in the world and also obtaining happiness in the hereafter.

For the life of the world, falah includes three definitions, namely survival, freedom of desire, and strength and honor. As for the afterlife, falah includes the meaning of eternal survival, eternal prosperity, eternal glory, and eternal knowledge (free from all ignorance). (Arif, Muhammad, 2018).

From the above information shows that happiness in the world is happiness that is obtained when there is survival in the world, getting freedom and the desire to get something. In this case it is defined as a person who is rich, kind hearted, rich in material, intelligent, grateful in his attitude and has a noble character. According to Muhammad SAW defining wealth is not only rich in material, but the heart is also wealth (Sitepu, Novi Indriyani, 2016). Finally, the form of world happiness is a leader who is able to produce better policies. Meanwhile, happiness in the hereafter cannot be seen directly because humans are still in the world, but not the human horns in the world can have an influence on happiness in the hereafter.

\section{Conclusion}

The description above can be concluded that sharia philosophy and sharia economic philosophy are related, because both are based on the Al-Quran, hadith, ijma 'and qiyas, as well as operational principles, observations are made, take generalization conclusions and serve as theory, while the goal is both want to get happiness in the world and the hereafter, but what distinguishes the two lies in the broader study of sharia philosophy and complexity, while Islamic economic philosophy specializes in sharia economic studies.

\section{References}

Achmad Gholib, Filsafat Islam (Jakarta: Feza Media, 2009)

Arif, Muhammad, Filsafat Ekonomi Islam (Medan, 2018)

Arwani, Agus, 'Epistemologi Hukum Ekonomi Islam (Muamalah)', EJournal.Iainpekalongan.Ac.Id, 15 No.1 (2012), 127

Banks J.A, Teaching Strategies for the Sosial Studiens (New York dan London, 1990)

Fauzia, IY, Prinsip Dasar Ekonomi Islam Perspektif Maqashid Al-Syariah, Prenadamed (Jakarta, 2014)

Harisah, A, Filsafat Pendidikan Islam Prinsip Dan Dasar Pengembangan (Yogyakarta, 2018)

Mohammadadib, Filsafat Ilmu: Ontologi, Epistemol Ogi, Aksiologi, Dan Logika Ilmu Pengetahuan (Yogyakarta, 2011)

Pospos, Ade Fadillah Fw, 'Fenomena Ekonomi Islam Di Tanah Rencong', Jurnal Perspektif Ekonomi Darussalam, 1 Nomor 2 (2015)

Ridha, muhammad Rasid, 'Landasan Filsafat Ekonomi Islam' 
Sitepu, Novi Indriyani, 'Prilaku Bisnis Muhammad SAW Sebagai Entrepreneur Dalam Filsafat Ekonomi Islam', Jurnal.Uinsu.Ac.Id, 3 No. 1 (2016), 22

Sulaiman, A, Mengenal Filsafat Islam (Bandug, 2016)

Syakh Muhammad Bin Abdul Wahab, Al-Jadid Penjelasan Lengkap Kitab Tauhid (Penerbit: Pustaka Imam Bonjol)

Wahyu, Bambang, 'Globalisasi Dan Tantangan Bagi Sistem Keuangan Islam: Perspektif Filsafat Ekonomi Islam’, Jurnal Ekonomi Islam Al-Infaq, 2.1 (2011), 5-12 